\title{
ABBREVIATIONS
}

All references to Chaucer's works are from L. D. Benson, ed., The Riverside Chaucer (Oxford, 1989) and are cited in the text by an abbreviated form of the title with a page or line reference. All other works are cited by its author or editor and date, with page numbers where appropriate. A full bibliography of references appears at the end of this volume. All biblical quotations are taken from Bishop Challoner's Douay-Rheims translation.

\section{ABBREVIATIONS USED IN TEXT AND NOTES}

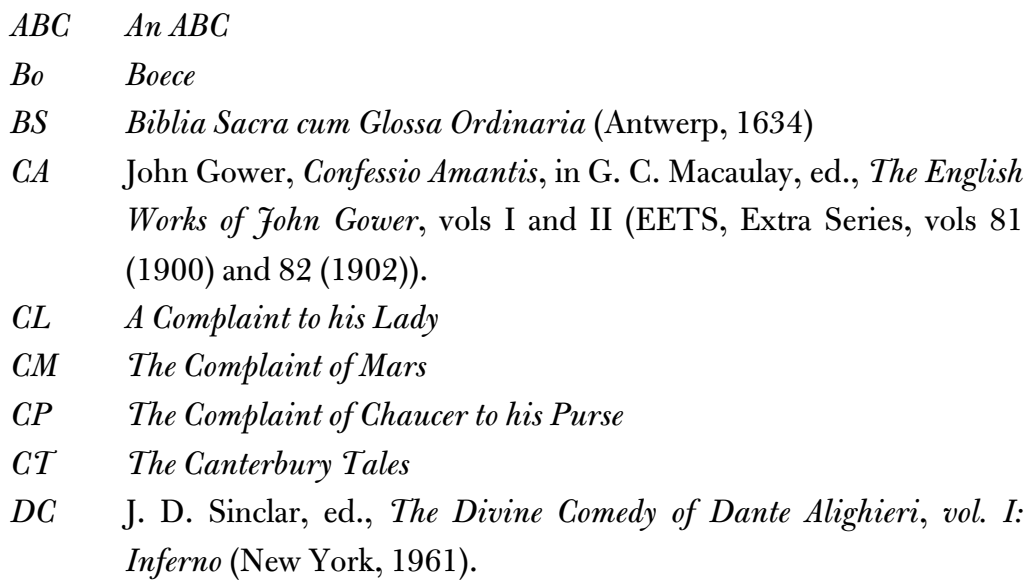

EETS Early English Text Society

Fo Fortune

HF The House of Fame

IPP John Gower, 'In Praise of Peace', in G. C. Macaulay, ed., The English Works of Fohn Gower, vol. II (EETS, Extra Series, vol. 82 (1902))

\section{LB Lenvoy de Chaucer a Bukton}

LGW The Legend of Good Women

MO Mirour de l'Omme, in G. C. Macaulay, ed., The Complete Works of fohn Gower: the French Works (Oxford, 1899)

PF The Parliament of Fowls

PL Patrologia Latina, ed. J. P. Migne, 221 volumes, Paris 1841-1905 
$P P B \quad$ William Langland, The Vision of Piers the Plowman: A Compete Edition of the B-Text, ed. A. V. C. Schmidt (London, 1989)

QR La Querelle de la Rose: Letters and Documents (North Carolina Studies in the Romance Languages and Literature, 199 (1978), eds J. L. Baird and J. R. Kane

ST Lydgate's Siege of Thebes, ed. A. Erdmann, Parts I and II (EETS, Extra Series, vols 108 (1911) and 125 (1930)

TC Troilus and Criseyde

VC John Gower, Vox Clamantis in G. C. Macaulay, ed., The Complete Works of John Gower, vol. IV: the Latin Works (Oxford, 1902) 